\title{
DELAYED NESTING BY FEMALE CANADA GEESE (BRANTA CANADENSIS): BENEFITS AND COSTS
}

\author{
Michael R. CONOVER ${ }^{1}$ \\ Department of Wildland Resources, Utah State University, Logan, Utah 84322, USA
}

\begin{abstract}
In many avian species, females do not nest the first year they attain sexual maturity. I examined the benefits and costs of delayed nesting in a nonmigratory population of Canada Geese (Branta canadensis) in New Haven County, Connecticut, from 1984 through 2008. I individually marked 381 female goslings and monitored them throughout their lives. Eighty-seven females were recruited into the local breeding population; 16 of these started nesting when 1 or 2 years old (young nesters), and 71 started nesting when 3 to 9 years old (delayed nesters). During their first reproductive effort, young nesters and delayed nesters produced similarsized clutches but young nesters produced fewer hatchlings or fledglings. Young nesters died sooner than delayed nesters, but the two groups were similar in number of years of life following first nesting effort, number of nesting years during life span, and total lifetime production of eggs, hatchlings, and fledglings. Both young nesters and delayed nesters had similar values of $\lambda^{(\mathrm{m})}$, which is an integrated measure of an individual's propensity fitness. Young nesters weighed more at fledging than delayed nesters, which suggests that larger and healthier females were more likely to become young nesters. Competition among Canada Geese for safe nesting sites on islands was keen in the study area. This may have contributed to the prevalence of delayed nesting because geese that were unable to secure a safe nesting site may have delayed nesting until the following year. Received 3 October 2011, accepted 14 December 2011.
\end{abstract}

Key words: age-specific reproduction, Branta canadensis, Canada Goose, delayed maturation, helpers, lambda, life expectancy, lifetime reproduction, precocious nesting.

\section{Anidación Retrasada en las Hembras de Branta canadensis: Costos y Beneficios}

RESUMEN.-En muchas especies de aves, las hembras no anidan el primer año después de que adquieren la madurez sexual. Examiné los costos y beneficios de la anidación retrasada en una población no migratoria de Branta canadensis en el condado de New Haven, Connecticut, desde 1984 hasta 2008. Marqué individualmente 381 gansas juveniles y las monitoreé a lo largo de sus vidas. Ochenta y siete hembras fueron reclutadas por la población reproductiva local; 16 de ellas empezaron a anidar al primer o segundo año de edad (anidantes jóvenes), y 71 empezaron a anidar cuanto tenían entre 3 y 9 años de edad (anidantes tardías). Durante su primer esfuerzo reproductivo, las anidantes jóvenes y las anidantes tardías produjeron nidadas de tamaño similar, pero las anidantes jóvenes produjeron menos pichones y volantones. Las anidantes jóvenes murieron más temprano que las anidantes tardías, pero ambos grupos fueron similares en el número de años de vida posteriores al primer esfuerzo de anidación, el número de años de anidación durante su vida, y la producción total de huevos, pichones y volantones a lo largo de sus vidas. Tanto las anidantes jóvenes como las tardías tuvieron valores similares de $\lambda^{\text {(m) }}$, que es una medida integrada de la aptitud de un individuo. Las anidantes jóvenes pesaron más al emplumar que las anidantes tardías, lo que sugiere que las hembras más grandes y saludables son más propensas a volverse anidantes jóvenes. La competencia dentro de $B$. canadensis por sitios seguros de anidamiento en islas fue aguda en el área de estudio. Esto pudo haber contribuido a la prevalencia de la anidación retrasada debido a que las hembras que no pudieron asegurar un sitio seguro para anidar pudieron haber retardado la anidación hasta el año siguiente.

IN MANY AVIAN species, females fail to nest when they first become physiologically able to do so, a phenomenon known as "delayed maturation" or "delayed nesting" (Cooch et al. 1999, Sedinger et al. 2001, Blas et al. 2009). Delayed nesters forgo the benefits of nesting at an early age; these include a higher probability of nesting at least once and more years of reproduction (Johnson et al. 1992). Delayed nesting is most prevalent in species in which young females reproduce less successfully than older ones (Rohwer 1992) or for which the cost of not nesting at a young age is partially mitigated by a long life span (Hawkins et al. 2012).

${ }^{1}$ E-mail: mike.conover@usu.edu

The Auk, Vol. 129, Number 1, pages 140-146. ISSN 0004-8038, electronic ISSN 1938-4254. (C 2012 by The American Ornithologists' Union. All rights reserved. Please direct all requests for permission to photocopy or reproduce article content through the University of California Press's Rights and Permissions website, http://www.ucpressjournals. com/reprintInfo.asp. DOI: $10.1525 /$ auk.2012.11217 
Many hypotheses have been proposed to explain delayed nesting from an evolutionary perspective, and these can be divided into two groups: constraint hypotheses and restraint hypotheses. Constraint hypotheses argue that some females are prevented from nesting at a young age because they lack the physiological capabilities, experience, or skills that are needed to reproduce successfully (Balbontin et al. 2007; Sergio et al. 2009a, b). For example, the nutritional costs of nesting are high for a female Canada Goose (Branta canadensis), which produces a large clutch of large eggs that it must incubate constantly for several weeks without help from its mate and with little opportunity to forage (Moser and Rusch 1989). In Montagu's Harrier (Circus pygargus), young females are less likely to nest than older females and are less successful when they do; these age differences are more pronounced when food shortages occur (Arroyo et al. 2007).

Restraint hypotheses propose that delayed nesters refrain from nesting early in life to avoid the costs of doing so. In these cases, costs include a decrease in life expectancy and a reduction in the ability to reproduce in later years (Blas et al. 2009). For example, Zack and Stutchbury (1992) hypothesized that delayed nesters are able to acquire dominance during their longer nonbreeding period and that this enhances their prospects of acquiring a high-quality territory and mate when they start nesting. Hence, delayed nesters may breed in fewer years during their lives than young nesters but may fledge more young during each year in which they nest.

The proximate mechanism for delayed nesting may be both exogenous and endogenous. Exogenous factors may include the lack of a suitable nesting territory or mate (Zack and Stutchbury 1992). Endogenous factors may be hormonal and influence the bird's readiness to reproduce or sensitivity to stress (Blas and Hiraldo 2010). Young Snow Petrels (Pagodroma nivea) are more sensitive to stress than older birds, and females with elevated corticosterone levels during the pre-laying period had a higher probability of not breeding (Goutte et al. 2010).

In Canada Geese, both males and females are capable of breeding when 1 year old (Wood 1964, Drobney et al. 1999) but most do not nest until they are at least 3 years old (MacInnes and Dunn 1988, Hardy and Tacha 1989). Here, I compare the survival and lifetime reproduction of female Canada Geese that started nesting at 1 or 2 years of age (young nesters) and those that waited until they were at least 3 years old to start nesting (delayed nesters). I hypothesized that young nesters, when nesting for the first time, would lay smaller clutches, have a smaller proportion of eggs that hatched, and produce fewer goslings that fledged than delayed nesters. I also hypothesized that young nesters would die at an earlier age than delayed nesters and would produce fewer eggs, hatchlings, and fledglings during their lifetimes.

\section{Methods}

The study was conducted in New Haven County, Connecticut, over a 25-year period (1984-2008). Several subspecies of Canada Geese (B. canadensis maxima, B. c. interior, and B. c. canadensis) contributed to the genetic origins of these Canada Geese, but they most closely resembled B. c. maxima (Pottie and Heusmann 1979). The geese in New Haven County were nonmigratory (Conover 2011). When inland waters froze during winter, geese moved temporarily to the nearby Connecticut coast on Long Island Sound but returned to inland ponds and lakes after thawing. Most Canada Geese in the county built their nests on islands in lakes and ponds scattered throughout the county, but many brought their broods to one of three brood-rearing sites. The three broodrearing sites were West River watershed (including Konold's Pond, Lake Waltrous, Lake Glen, and Lake Dawson), Whitney Lakes, and Maltby Lakes (Fig. 1). Adjacent to these lake complexes were golf courses, shopping centers, and apartment buildings; broods usually foraged on lawns associated with these areas. For instance, broods from the Maltby Lakes spent most of their time on Yale University Golf Course, which offered both rich foraging grounds (lawns) and sanctuaries (water hazards and ponds). Such open sites were ideal for keeping track of individual Canada Geese and their goslings.

In late June, adult Canada Geese in Connecticut molt their primary feathers and become flightless. This molt occurs immediately before the goslings begin to fly. During the molt, I captured goslings and adults at the brood-rearing sites by driving them into funnel traps. Most of the adults and goslings at these sites were captured, but some escaped. I weighed each bird upon capture and determined its sex through a cloacal examination. I placed on each bird a federal band and either a large, individually numbered leg band with 1.3-cm-high letters and numbers or a neck collar with 3 -cm-high numbers and letters on adult birds. These large leg bands and neck collars, made by Spinner Plastics (Springfield, Illinois), allowed me to identify the geese individually. The collars were identical to those used extensively throughout the Atlantic Flyway (Hestbeck and Malecki 1989). I replaced federal bands, large leg bands, or neck collars when they wore out or were lost. I restricted my analysis to female Canada Geese banded as goslings prior to 2000. Geese banded after 2000 were excluded from analyses because I was interested in lifelong reproduction and birds banded after 2000 might still have been alive at the end of

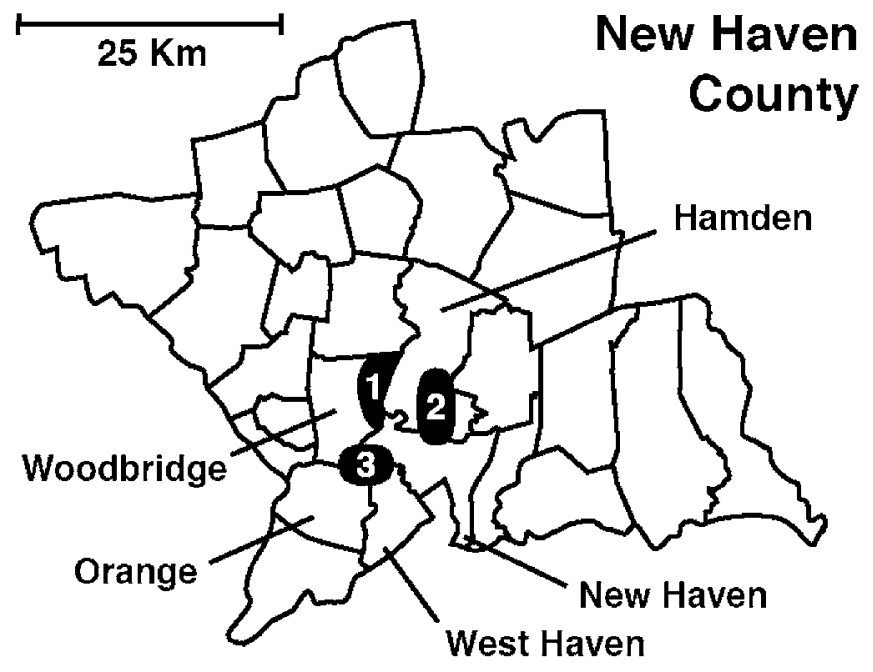

FIG. 1. Map of New Haven County, Connecticut, showing the three areas where Canada Geese brought their broods: (1) West River watershed, (2) Whitney Lakes, and (3) Maltby Lakes. The boundaries of the towns and cities that make up the county are also shown. 
the observation period (2008). In most years, I or my technicians tracked my female geese year-round by searching about 50 sites in Connecticut that were used by geese for feeding, loafing, or roosting. I saw most of my subjects repeatedly throughout the year. I assumed that a goose died during the year when my observations of it ceased, I found its dead body, or I received a report of its death from the U.S. Bird Banding Laboratory. The U.S. Bird Banding Lab received mortality reports for 77 females that were banded as goslings (20\% recovery rate). All but six of the mortalities occurred in Connecticut; only one recruited female was ever seen or killed outside of Connecticut.

I visited known nesting sites in New Haven County several times during the nesting season to identify which Canada Geese were paired together and which defended territories, and to locate nest sites. I found nests by systematically searching the shore and islands for them and by watching for single males; the presence of a single male usually meant that a nest was nearby. I considered females to have nested during any year in which they were observed incubating a nest or were seen with a brood. Recruited geese were those individuals that nested at least once during their lives. Once a female was recruited into the local breeding population, it rarely left New Haven County, and none was observed nesting outside the county (Conover 2011).

I visited each nest during the incubation period, usually twice, to count eggs. Additionally, I observed each nest from a distance to determine whether it was still being incubated. Nests were checked to determine their fate as soon as possible after the female stopped incubating. Each year in which one of my subjects nested, I recorded its age, its leg band or collar number, and that of its mate. I determined its clutch size, number of hatchlings (brood size immediately after hatching), and number of fledglings (brood size immediately before capture). Broods were counted on nesting territories and soon after they reached the brood-rearing site. I visited most of them at least weekly for the first month after they arrived and then every week or two until the goslings could fly (mid-July) to determine brood size and identify which goslings and parents were present. Broods were identified by which parents attended them. Individual goslings were not marked at hatching, but many broods were dyed or marked with ink at hatching to distinguish them from other broods. I assumed that parents had lost their entire brood when they were observed by themselves and none of their goslings were observed with another brood. I sometimes failed to find a nest before the eggs hatched. When this happened, I assumed that the clutch size was identical to their number of hatchlings. This will make my estimates of clutch sizes conservative because I am not accounting for any unhatched eggs or goslings that died prior to my locating the brood. In New Haven County, $72 \%$ of eggs hatched in successful nests and $81 \%$ of goslings survived from hatching until fledging (M. R. Conover unpubl. data).

Some parents raised their goslings without help from other adults, whereas others joined with other parents to form a "gang brood," which is defined as two or more families joining together with their offspring and creating a cohesive group of young accompanied by four or more parents (Gosser and Conover 2000). I could usually determine how many hatchlings each adult pair contributed to a gang brood by observing each pair's brood prior to the formation of the gang brood. When I could not do so, I divided the total number of hatchlings in a gang brood by the number of attending pairs of adults and used this mean as the number of hatchlings produced by an adult pair. Likewise, the number of fledglings produced by each pair of adults attending a gang brood was determined by dividing the total number of fledglings in a gang brood by the number of attending adult pairs.

Some non-nesting geese served as brood helpers. These individuals were in constant contact with a brood and helped herd the brood and defended it from other Canada Geese. I identified a helper by noting its leg bands and collars and those of its parents. Parents and offspring rarely formed gang broods with each other (Conover 2009). I was able to distinguish helpers from young nesters because helpers were associated with their parents whereas 1-year-old nesters were paired with an unrelated individual. Also, most helpers did not incubate a nest but all young nesters did. I considered a helper's first nesting attempt to have occurred when it first nested with an unrelated goose.

My ability to assess lifelong reproduction was dependent on my ability to locate my subjects each year that they fledged young. There was a risk that a subject would not use the same area to nest throughout its entire life or the same site to raise its brood. To assess this risk, I determined the proportion of birds that nested in different lake complexes or used different brood-rearing sites during their lives.

For each recruited female, I counted clutch size, brood size at hatching, and brood size at fledging during its first and all future nesting attempts. For each recruited goose that nested twice, I determined the number of years between its first and second nesting attempts. For all recruited geese, I tallied the number of years the individual nested during its lifetime and its lifetime production of eggs, hatchlings, and fledglings. I also determined its age when it first nested, its age at death, and the number of future years of life that remained when it first nested. For each recruited goose, I determined $\lambda^{(\mathrm{m})}$, which is an integrated measure of an individual's propensity fitness, using the method of McGraw and Caswell (1996). For each dependent variable, I compared young nesters to delayed nesters using a Student's $t$-test. If variances were unequal ( $F$-test), I used an unpaired, two-tailed Student's $t$-test for unequal variances (Siegel 1956) using NCSS (NCSS, Kaysville, Utah). For all tests, statistical results were considered significant when $P<0.05$. For all tests, each recruited female served as the experimental unit. Results are reported as means \pm SD.

\section{RESUlts}

I banded 381 female goslings, and 87 were recruited into the breeding population (23\%). Once females started to nest, they exhibited strong fidelity to both nest site and brood-rearing site. Only one female switched to a different lake complex to nest during its life, and this same female was also the only one that switched broodrearing sites during its life.

Nine females (2.4\% of all females banded as goslings) paired with an unrelated male and started nesting when they were 1 year old, and seven different females (1.8\%) started nesting when they were 2 years old. There were no differences between these two groups of females in any of the dependent variables. Hence, they were combined into a single group (young nesters) for further analyses. 


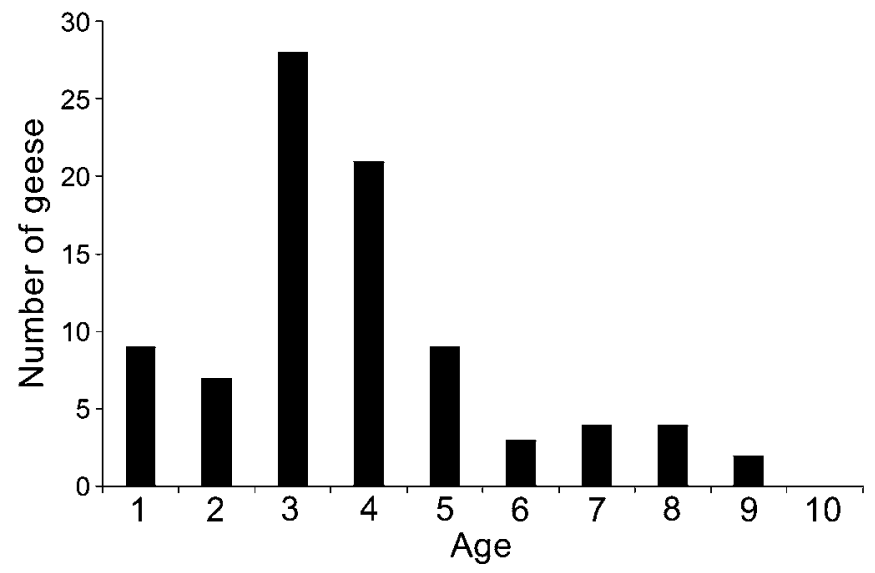

FIG. 2. Age of female Canada Geese when nesting for the first time. All geese were banded as goslings in New Haven County, Connecticut.

Seventy-one females started nesting when they were over 2 years old (delayed nesters). Delayed nesters ranged in age from 3 to 9 years old when nesting for the first time, but most started nesting when they were 3 or 4 years old (Fig. 2). On their first nesting attempt, young nesters were $1.4 \pm 0.5$ years old and delayed nesters were $4.4 \pm 1.6$ years old. Body mass at fledging differed between young and delayed nesters $(t=2.10, \mathrm{df}=82, P=0.04)$, with young nesters being heavier $(2,775 \pm 661 \mathrm{~g})$ than delayed nesters $(2,546 \pm 407)$. After their first nesting season, body masses of young nesters $(3,703 \pm 325 \mathrm{~g})$ and delayed nesters $(3,650 \pm 402)$ were similar $(t=0.39, \mathrm{df}=36, P=0.76)$.

Young nesters and delayed nesters produced similar-sized clutches during their first nesting season (Table 1). However, young nesters were significantly less successful than delayed nesters during incubation and brood rearing. Young nesters produced half the number of hatchlings and fledglings as delayed nesters during their first nesting effort (Table 1). The number of years separating first and second nesting efforts were similar for young nesters and delayed nesters.

Young nesters died at a younger age $(5.0 \pm 4.4$ years $)$ than delayed nesters $(7.1 \pm 3.1$ years). Despite this, young nesters and delayed nesters had similar numbers of future years of life when they first nested; both groups also nested in similar numbers of years during their lifetimes (Table 1). Lifetime production of eggs, hatchlings, and fledglings were also similar for young nesters and delayed nesters. Values of $\lambda^{(\mathrm{m})}$ for young nesters $(0.81 \pm 0.96)$ were smaller than those for delayed nesters $(1.01 \pm 0.51)$, but the differences were not statistically significant (Table 1). Although not included in the analysis, four males also paired with an unrelated female when they were only 1 year old; three of the four nests failed during the incubation period, but the one successful nest fledged five goslings. Five females $(1.3 \%$ of all females banded as goslings) helped their parents raise their brood when they were 1 year old. No males became helpers, and no females did so after they were 1 year old.

\section{Discussion}

It is difficult to determine lifelong reproduction of free-ranging birds because the probability of detecting nesting attempts is usually $<1.0$ (Desprez et al. 2011). However, I believe that I found nearly all nesting attempts because I searched for nesting females three times each year: during spring when the females were incubating nests, during summer when they attended their broods, and during fall when they remained with their fledged young. Despite these efforts, there undoubtedly were some nesting geese that I did not locate. Regardless, if a goose nested and raised its brood in a location where over its lifetime it went undetected, it would have no effect on my comparison of young and delayed breeders. On the other hand, if I located a nesting goose in some years but not in others, my estimates of lifetime reproduction would be conservative or might differ between young and delayed breeders. My data show, however,

TABLE 1. Comparison between 16 female Canada Geese that first nested when they were $1-2$ years old (young nesters) and 61 females that first nested when they were $>2$ years old (delayed nesters) in their reproductive effort during the first year of nesting and lifetime effort. Canada Geese were banded as goslings in New Haven County, Connecticut, from 1984 through 1999 and followed through 2008.

\begin{tabular}{|c|c|c|c|c|c|}
\hline & Young nesters & Delayed nesters & & & \\
\hline Characteristic & Mean \pm SD & Mean \pm SD & df & $t$ & $P$ \\
\hline \multicolumn{6}{|l|}{ First year of nesting } \\
\hline Clutch size & $3.9 \pm 1.7$ & $4.1 \pm 2.1$ & 85 & 0.21 & 0.83 \\
\hline Number of hatchlings & $1.6 \pm 1.8$ & $3.2 \pm 2.6$ & $40.2^{\mathrm{a}}$ & 3.08 & 0.004 \\
\hline Number of fledglings & $1.4 \pm 1.8$ & $2.8 \pm 2.9$ & 47.9 & 2.58 & 0.01 \\
\hline Years separating first and second nesting & $2.0 \pm 1.4$ & $1.5 \pm 1.2$ & 40 & 1.02 & 0.31 \\
\hline Future years of life at first nesting & $2.9 \pm 4.7$ & $2.6 \pm 2.7$ & 17.7 & 0.19 & 0.86 \\
\hline Age at death & $4.3 \pm 4.6$ & $7.0 \pm 3.1$ & 85 & 2.82 & 0.006 \\
\hline \multicolumn{6}{|l|}{ Lifetime reproduction } \\
\hline Number of nesting years & $2.2 \pm 2.4$ & $2.1 \pm 1.5$ & 21.1 & 0.15 & 0.88 \\
\hline Number of eggs & $8.3 \pm 9.0$ & $9.2 \pm 8.6$ & 85 & 0.38 & 0.71 \\
\hline Number of hatchlings & $5.5 \pm 8.2$ & $6.9 \pm 7.0$ & 85 & 0.75 & 0.46 \\
\hline Number of fledglings & $5.3 \pm 8.8$ & $6.1 \pm 6.8$ & 85 & 0.44 & 0.66 \\
\hline$\lambda^{(\mathrm{m})}$ & $0.81 \pm 0.96$ & $1.01 \pm 0.51$ & 17.2 & 0.80 & 0.43 \\
\hline
\end{tabular}

${ }^{a}$ When degrees of freedom are reported to the 10th place, I used a $t$-test for unequal variances. 
that only 1 of 87 females nested in two different lake complexes during its lifetime, and this same bird was the only one that used two brood-rearing sites. Thus, because female Canada Geese exhibited great fidelity to both nest and brood-rearing sites once they started to breed, I am confident that my nesting records are virtually complete. Because I have no reason to believe that my ability to locate nests and broods of young and of delayed nesters differed, I am equally confident in my comparison of lifetime reproductive success of young and delayed breeders.

Why are young birds less successful than older birds when reproducing?-In many avian species, young females are less successful when reproducing than older ones; young females produce smaller eggs, clutches, and broods and fewer fledglings (Hatch and Westneat 2007, Hawkins et al. 2012). At my study site, young and delayed nesters had similar-sized clutches. By contrast, others have reported that young Canada Geese produce smaller clutches than older Canada Geese (Brakhage 1965, Cooper 1978, Raveling 1981). I found that young nesters had smaller brood sizes at hatching and fledging than delayed nesters. Similarly, Raveling (1981) discovered that younger Canada Geese were more likely than older parents to lose young from their broods, and Wang (1982) found that older parents had higher gosling survival than younger parents.

Two hypotheses have been proposed to explain why young birds often breed less successfully than older birds. The first, the "physiological-condition hypothesis," argues that younger birds are in poorer condition than older birds (Lack 1968). Assuming that body mass at fledging is positively correlated with body mass at first reproduction, my results are inconsistent with this hypothesis because young nesters were heavier at fledging than delayed nesters. That body mass at the end of the first breeding attempt did not differ between young and delayed breeders also suggests that young breeders were not in poorer physiological condition than delayed nesters. The "nesting-experience hypothesis" states that older birds are more likely to have nested previously than younger ones and that this experience allows them to be more successful (Balbontin et al. 2007, Desprez et al. 2011). It is difficult to test this hypothesis because increasing age and greater nesting experience are autocorrelated. Some have teased the effects of these two variables apart by comparing birds of the same age that differ in their years of prior nesting experience. In many avian species, individuals with and without prior nesting experience have similar nesting success when age is held constant (Rohwer 1992); but in geese, prior nesting experience increases nesting success. In Barnacle Geese (Branta leucopsis), experienced nesters had larger clutches and earlier hatching dates than naive nesters, both of which contribute to greater reproductive success (Forslund and Larsson 1992). Among Canada Geese, naive nesters took more incubation breaks than experienced nesters (Aldrich and Raveling 1983). These incubation breaks delayed hatching and reduced both the proportion of nests from which at least one egg hatched and the proportion of eggs that hatched from successful nests (Harvey 1971, Inglis 1977, Aldrich and Raveling 1983). Here, I took the opposite approach by holding years of prior nesting experience constant and allowing age to vary. Among first-time breeders, I found that young and delayed nesters had similar-sized clutches, but young nesters hatched fewer of their eggs and kept fewer of their hatchlings alive long enough to fledge. Hence, young nesters were as capable as delayed nesters of producing a clutch of eggs, but they appeared to lack the skill, stamina, or perseverance required to get their eggs to hatch or the hatchlings to fledge.

Why do the ages of sexual maturity and of maturation differ in Canada Geese?-My data indicate that female Canada Geese are sexually mature and physiologically capable of breeding when they are 1 year old, a finding that others have also made (Wood 1964, Brakhage 1965). However, the proportion of 1-year-old females that nest varies among locations, ranging from $4 \%$ in Connecticut (present study) and 5\% in Missouri (Brakhage 1965), down to 1\% in Northwest Territories of Canada (MacInnes and Dunn 1988), 0\% in Illinois and Wisconsin (Hardy and Tacha 1989), and $0 \%$ in Montana (Craighead and Stockstad 1964). Most Canada Geese in Connecticut did not start to nest until they were at least 3 years old, and even then, the start of reproduction was a gradual process that on a population level extended over several years. Others have also observed delayed maturation in geese, but recruitment into the breeding population elsewhere is more abrupt than I observed in Connecticut (Craighead and Stockstad 1964, Brakhage 1965, MacInnes and Dunn 1988, Hardy and Tacha 1989). For example, in Greater Snow Geese (Chen caerulescens atlantica), recruitment started at the age of 2 years and was completed by the age of 4 years; that is, all 4-year-old females were nesting (Reed et al. 2003).

Life history theory predicts that the age of maturation should reflect both the liabilities and benefits of being a young nester versus a delayed nester (Johnson et al. 1992). Potential liabilities of nesting at a young age include higher probability of mortality than that of non-nesters of the same age. This might occur if nesting is nutritionally costly such that it causes nesting birds to be in poorer physiologically condition than non-nesters by the end of the nesting season (Bell 1980). In Canada Geese, I found that young nesters and delayed nesters had similar life expectancy (future years of life) once they began to breed. Another potential liability of early maturation is that nesting at a young age may impair the bird's future reproductive ability even though the parents' probability of death is unaffected. However, I found that lifetime reproduction rates of young nesters and delayed nesters were similar. Hence, there was no evidence that young nesters suffered impairment to their future reproductive ability by nesting at a young age. The potential benefits of early maturation include a higher probability of nesting at least once because of a shorter juvenile period, and more total years of reproduction (Hawkins et al. 2012). I found that young nesters and delayed nesters were similar in their total number of nesting years during their lifetimes. Hence, it appears that the benefits and liabilities of being a young nester counterbalanced each other.

Surprisingly, $\lambda^{(\mathrm{m})}$, a measure of how quickly an individual's genes are passed to the next generation (McGraw and Caswell 1996), was slightly lower for young nesters than for delayed nesters. Typically, $\lambda^{(\mathrm{m})}$ varies inversely with age at first reproduction. Hence, a gosling that is fledged during a parent's second year of life will increase $\lambda^{(\mathrm{m})}$ more than a gosling fledged later in a parent's life. The low $\lambda^{(\mathrm{m})}$ for young nesters $\left(\lambda^{(\mathrm{m})}=0.81\right)$ resulted because many young nesters were unsuccessful in fledging any young during their lives, resulting in $\lambda^{(\mathrm{m})}=0$. Other young nesters produced many fledglings, and this generated high variability of $\lambda^{(\mathrm{m})}$ among young nesters, and possibly accounts for absence of a difference in $\lambda^{(\mathrm{m})}$ between young and delayed breeders. 
Individuals in my study ranged in age from 1 to 9 years when they nested for the first time, and this raises the question of why there is such large variation in the age of maturation within a single population. One explanation is that non-nesting adult birds are those that were unable to find either a suitable mate or nesting territory by the start of the nesting season. If this "poor mate, poor territory hypothesis" is correct, delayed nesting should occur where territories or mates are in short supply. In New Haven County, safe nesting territories on islands are in short supply, and Canada Geese compete for them (Gosser and Conover 1999). Canada Geese that are unable to secure a safe nest site may decide to wait until the following year to nest rather than nest on the mainland, where incubating females have a higher risk of being killed by a mammalian predator. All females may start to seek a mate and nesting territory when they are 1 or 2 years old, but only the few that are successful become young nesters. The majority are then forced to delay nesting until opportunities exist and they acquire a mate and safe nesting territory.

\section{ACKNOWLEDGMENTS}

I thank G. C. Chasko, M. Huang, P. Merola, and many others with the Connecticut Department of Environmental Protection for their help banding geese for $>25$ years; G. Chasko, A. DiNicola, S. Hoover, A. Gosser, G. Kania, B. Lynn, P. Merola, P. Picone, and S. Williams for help collecting the data; and J. Dinkins, J. Fusaro, P. Jackson, M. Haney, S. Mabray, and T. Roberts for editorial help. Thanks to South Central Connecticut Regional Water Authority, Yale University Golf Course, apartment complexes, homeowners, businesses, and the cities of New Haven and Hamden for access to their property. This study was funded by the Connecticut Agricultural Experiment Station, Utah Agricultural Experiment Station, and U.S. Department of Agriculture Wildlife Services.

\section{Literature Cited}

Aldrich, T. W., AND D. G. Raveling. 1983. Effects of experience and body weight on incubation behavior of Canada Geese. Auk 100:670-679.

Arroyo, B. E., V. Bretagnolle, And A. Leroux. 2007. Interactive effects of food and age on breeding in Montagu's Harrier Circus pygargus. Ibis 149:806-813.

Balbontin, J., I. G. Hermosell, A. Marzal, M. Reviriego, F. De Lope, ANd A. P. Møller. 2007. Age-related change in breeding performance in early life is associated with an increase in competence in the migratory Barn Swallow Hirundo rustica. Journal of Animal Ecology 76:915-925.

BELL, G. 1980. The costs of reproduction and their consequences. American Naturalist 116:45-76.

Blas, J., AND F. Hiraldo. 2010. Proximate and ultimate factors explaining floating behavior in long-lived birds. Hormones and Behavior 57:169-176.

Blas, J., F. Sergio, and F. Hiraldo. 2009. Age-related improvement in reproductive performance in a long-lived raptor: A crosssectional and longitudinal study. Ecography 32:647-657.

BrakHage, G. K. 1965. Biology and behavior of tub-nesting Canada Geese. Journal of Wildlife Management 29:751-771.

Conover, M. R. 2009. Gang brooding in Canada Geese: Role of parental condition and experience. Condor 111:276-282.
Conover, M. R. 2011. Population growth and movements of non-migratory Canada Geese in Connecticut. Waterbirds 34:412-421.

Cooch, E. G., D. B. Lank, R. F. Rockwell, And R. Cooke. 1999. Body size and age of recruitment in snow geese Acer c. caerulescens. Bird Study 46 (Supplement):S112-S119.

Cooper, J. A. 1978. The history and breeding biology of the Canada Geese of Marshy Point, Manitoba. Wildlife Monographs, no. 61.

Craighead, J. J., AND D. S. Stockstad. 1964. Breeding age of Canada Geese. Journal of Wildlife Management 28:57-64.

Desprez, M., R. Pradel, E. Cam, J.-Y. Monnat, and O. Gimenez. 2011. Now you see him, now you don't: Experience, not age, is related to reproduction in Kittkwakes. Proceedings of the Royal Society of London, Series B 278:3060-3066.

Drobney, R. D., J. M. Checkett, J. M. Coluccy, and D. A. GRABER. 1999. Precocious breeding by yearling giant Canada Geese. Auk 116:1145-1147.

Forslund, P., And K. LARsson. 1992. Age-related reproductive success in the Barnacle Goose. Journal of Animal Ecology 61:195-204.

Gosser, A. L., ANd M. R. Conover. 1999. Will the availability of insular nesting sites limit reproduction in urban Canada Goose populations? Journal of Wildlife Management 63:369-373.

Gosser, A. L., And M. R. Conover. 2000. Potential influence of climate and habitat factors on cooperative brood-rearing in Canada Geese. Ethology 106:235-246.

Goutte, A., É. Antoine, H. Weimerskirch, and O. Chastel. 2010. Age and the timing of breeding in a long-lived bird: A role for stress hormones? Functional Ecology 24:1007-1016.

HaRdy, J. D., AND T. C. TACHA. 1989. Age-related recruitment of Canada Geese from the Mississippi Valley population. Journal of Wildlife Management 53:97-98.

Harvey, J. M. 1971. Factors affecting Blue Goose nesting success. Canadian Journal of Zoology 49:223-234.

Hatch, M. I., And D. F. Westneat. 2007. Age-related patterns of reproductive success in House Sparrows Passer domesticus. Journal of Avian Biology 38:603-611.

Haw kins, G. L., G. E. Hill, and A. Mercadante. 2012. Delayed plumage maturation and delayed reproductive investment in birds. Biological Reviews 87: in press.

HestbeCK, J. B., AND R. A. MALECKI. 1989. Estimated survival rates of Canada Geese within the Atlantic Flyway. Journal of Wildlife Management 53:91-96.

INGLIS, J. R. 1977. The breeding behaviour of the Pink-Footed Goose: Behavioural correlates of nesting success. Animal Behaviour 25:747-764.

Johnson, D. H., J. D. Nichols, And M. D. Schwatz. 1992. Population dynamics of breeding waterfowl. Pages 446-485 in Ecology and Management of Breeding Waterfowl (B. D. J. Batt, A. D. Afton, M. G. Anderson, C. D. Ankney, D. H. Johnson, J. A. Kadlec, and G. L. Krapu, Eds.). University of Minnesota Press, Minneapolis.

LACK, D. 1968. Ecological Adaptations for Breeding in Birds. Methuen, London.

MaCInnes, C. D., AND E. H. DunN. 1988. Estimating proportion of an age class nesting in Canada Geese. Journal of Wildlife Management 52:421-423.

McGraw, J. B., AND H. CASwell. 1996. Estimation of individual fitness from life-history data. American Naturalist 147:47-64. 
Moser, T. J., And D. H. Rusch. 1989. Age-specific breeding rates of female Interior Canada Geese. Journal of Wildlife Management 53:734-740.

Pottie, J. J., And H. W. Heusmann. 1979. Taxonomy of resident Canada Geese in Massachusetts. Transactions of the Northeast Section of the Wildlife Society 36:132-137.

RavelinG, D. G. 1981. Survival, experience, and age in relation to breeding success of Canada Geese. Journal of Wildlife Management 45:817-829.

Reed, E. T., G. Gauthier, R. Pradel, and J.-D. Lebreton. 2003. Age and environmental conditions affect recruitment in Greater Snow Geese. Ecology 84:219-230.

ROHWER, F. C. 1992. The evolution of reproductive patterns in waterfowl. Pages 486-539 in Ecology and Management of Breeding Waterfowl (B. D. J. Batt, A. D. Afton, M. G. Anderson, C. D. Ankney, D. H. Johnson, J. A. Kadlec, and G. L. Krapu, Eds). University of Minnesota Press, Minneapolis.

Sedinger, J. S., M. S. Lindberg, and N. D. Chelgren. 2001. Agespecific breeding probability in Black Brant: Effects of population density. Journal of Animal Ecology 70:798-807.
Sergio, F., J. Blas, R. Baos, M. G. Forero, J. A. Donázar, and F. Hiraldo. 2009a. Short- and long-term consequences of individual and territory quality in a long-lived bird. Oecologia 160:507-514.

Sergio, F., J. Blas, and F. Hiraldo. 2009b. Predictors of floater status in a long-lived bird: A cross-sectional and longitudinal test of hypotheses. Journal of Animal Ecology 78:109-118.

Siegel, S. 1956. Nonparametric Statistics for the Behavioral Sciences. McGraw-Hill, New York.

WANG, Y. T. 1982. Factors affecting hatching success and gosling survival in Canada Geese. Ph.D. dissertation, Ohio State University, Columbus.

Wood, J. S. 1964. Normal development and causes of reproductive failure in Canada Geese. Journal of Wildlife Management 28:197-208.

ZACK, S., AND B. J. StutChbuRY. 1992. Delayed breeding in avian social systems: The role of territory quality and "floater" tactics. Behaviour 123:194-219.

Associate Editor: G. R. Hepp 